\title{
ANALISIS UKURAN PORI BIOKOMPOSIT [SERICIN-BIOPLASTIK] PADA BERBAGAI PEMBEKUAN DENGAN METODE TAGUCHI
}

\author{
Gaustama Putra*1 \\ ${ }^{1}$ Program Studi Teknik Industri, Fakultas Teknik, Universitas Teuku Umar \\ Email: ${ }^{* 1}$ ghostamaputra79@gmail.com
}

\begin{abstract}
Increased demand for medical materials, triggering research into alternative medical materials. Alternative materials should have the same characteristics for the patient's body. Sericin is a protein that has biocompatible, biodegradable and other important properties. Sericin is widely used in biomedical applications, it is thought that sericin is a promising natural resource as an alternative medical material. This study analyzed pore diameter in sericin-bioplastic biocomposites by Taguchi method. Bioplastics of 3 variations of tapioca starch were $16 \mathrm{~g}, 14 \mathrm{~g}$, and $10 \mathrm{~g}$, mixed $80 \mathrm{ml}$ of aquades and $6 \mathrm{ml}$ of glycerin. Sericin was determined $0.03 \%, 0.1 \%$, and $0.3 \%$ by weight of tapioca starch. The biocomposite undergoes freeze drying process and is frozen at $-25 \mathrm{oC}$, $-45 o C$, and $-80 o C$ for one day. SEM test to see pore diameter and biocomposite structure. Optimal analysis was performed for optimal combinations of sericin-bioplastic biocomposites.

The SEM results showed pore diameters qualified for regeneration of skin tissue on freezers $C-C, F$, and I-25oC biocomposites of $41.94 \mu \mathrm{m}, 33.416 \mu \mathrm{m}$ and $32.743 \mu \mathrm{m}$ respectively. Calculation of average response and maximum SNR at $16 \mathrm{~g}$ tapioca starch, $0.03 \%$ sericin and -25oC temperature. The predicted and confidence interval values for averages are large from 11,656 $\mu \mathrm{m}$ and small from 54,602 $\mu \mathrm{m}$, SNR is large from 31,940 $\mu \mathrm{m}$ and small from 33,642 $\mu \mathrm{m}$. The optimal experimental conditions for confirmation of large pore diameter for averages were large from $32.342 \mu \mathrm{m}$ and small from $34.206 \mu \mathrm{m}$, large SNR of $32.342 \mu \mathrm{m}$ and small from $34.206 \mu \mathrm{m}$.
\end{abstract}

Keywords: Composition optimization, alternative medical materials, sericin-bioplastic biocomposites, Taguchi Methods, SEM

\section{PENDAHULUAN}

Meningkatnya kebutuhan akan bahan biomaterial dalam bidang medis untuk berbagai keperluan terus meningkat dewasa ini. Hal ini antara lain disebabkan oleh tingginya angka kecelakaan serta meningkatnya kasus kebakaran yang menimbulkan luka bakar yang serius pada korban. Selain itu berbagai kasus penyakit seperti penyakit kanker tulang, patah tulang dan lain-lain yang memerlukan graft tulang sintesis. Saat ini produk biomaterial di Indonesia sebagian besar merupakan produk impor dengan harga sangat mahal, serta memerlukan waktu lama di saat produk dibutuhkan.

Berdasarkan hal tersebut memicu perkembangan penelitian dengan berbagai macam metode untuk mendapatkan bahan biokomposit medis alternatif. Penelitian 
dilakukan dengan menggunakan material mudah didapat karena ketersediaan yang melimpah di alam, harga murah, dan ramah lingkungan. Material yang digunakan harus bersifat biocompatible, biofunctional, dan memiliki karakteristik yang baik bagi tubuh penderita. Material diteliti dengan mendalam agar mempunyai persamaan bentuk dan sifat dengan material yang sudah ada. Penelitian yang dilakukan seperti sifat utama material, karakterisasi dari bahan setelah diproses silang, tingkat pori yang terbentuk, perkembangan sel, kadar toksik dan lainnya agar material cocok dan bisa sebagai bagian pengganti pada tubuh pengguna.

Pada riset sebelumnya, telah berhasil dibuat bahan hidroksiapatit untuk cangkok tulang biokramik dari sumber alami (gipsum, kalsit, tulang sapi dan cangkang sotong) [1]. Sementara sintesis makroporos komposit kolagen-hidroksiapatit sebagai kandidat bone graft, kolagen disintesis dari cakar ayam. Hasil penelitian mengatakan bahwa kontrol waktu pembekuan mempengaruhi ukuran makroporos dan sifat mekaniknya [2].

Sericin berasal dari kokon ulat sutera Bombyx mori (gambar 1). Protein utama yang terkandung di dalam kokon ulat sutera Bombyx mori, yaitu serat $75 \%$ dan sericin $25 \%$. Sericin dapat dengan mudah dihilangkan dalam proses degumming.

Sericin bersifat hidrofilik, terdiri dari 17-18 asam amino yang sebagian besar memiliki gugus samping polar yang kuat seperti kelompok hidroksil, karboksil dan amino serta banyak mengandung serin yang berkontribusi terhadap sifat yang sangat hidrofilik [3].

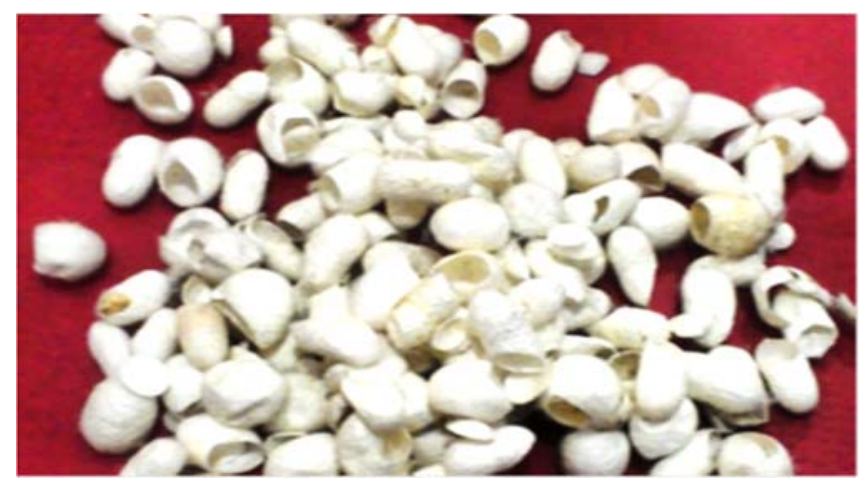

Gambar 1. Kokon Ulat Sutera Bombyx mori

Dalam bidang kedokteran sericin biasanya disilang dengan polimer lain dalam membentuk perancah untuk mendapatkan sifat yang lebih baik pada aplikasi biomedis.

Pati tapioka mengandung bakteri selulosa yang banyak diaplikasikan dalam dunia medis, di antaranya adalah memberikan perawatan pada luka bakar dan dapat juga dijadikan sebagai benang jahit dalam pembedahan [4], dikarenakan bakteri selulosa memiliki kandungan air tinggi, penyerap cairan yang baik, bersifat non-alergenik, dan aman ketika disterilisasi tanpa menyebabkan perubahan karakteristiknya [5].

Tujuan penelitian ini adalah menganalisa diameter pori yang terbentuk dan optimasi campuran biokomposit sericin-bioplastik dengan menggunakan metode Taguchi. Uji SEM dilakukan untuk melihat diameter pori dan struktur yang terbentuk pada biokomposit sericin-bioplastik yang mengalami proses pembekuan pada suhu $-25^{\circ} \mathrm{C}$, $45^{\circ} \mathrm{C}$, dan $-80^{\circ} \mathrm{C}$. Harapan penelitian ini didapatkan campuran optimal dan diameter pori yang cocok dan memenuhi syarat yang ditenukan untuk meregenerasi kulit maupun tulang dan dapat digunakan sebagai bahan medis alternatif yang bersumber dari alam, murah, mudah didapat, dan alami. 


\section{METODOLOGI PENELITIAN}

Bioplastik berasal dari pati tapioka (PT) dengan berat $16 \mathrm{~g}, 14 \mathrm{~g}$, dan $10 \mathrm{~g}$ dicampur dengan $6 \mathrm{ml}$ gliserin $(\mathrm{G})$ dan $80 \mathrm{ml}$ aquades (A) dalam gelas ukur, diaduk menggunakan magnetic stirrir kecepatan $600 \mathrm{rpm}$, suhu $50^{\circ} \mathrm{C}$ selama 7 menit (Tabel 1). Sericin dari kepompong ulat sutera Bombyx mori. direndam dalam 1 liter $n$-hexane di beaker glass selama 20 detik untuk menghilangkan wax dan dikeringkan. Selanjutnya kepompong dicampur dengan 2,3 liter aquades dan dilakukan proses autoclaving pada suhu $120^{\circ} \mathrm{C}$ selama 30 menit. Kepompong disaring menggunakan kertas filter ukuran $\pm 11 \mu \mathrm{m}$ untuk memisahkan larutan sericin dan serat, selanjutnya proses freeze drying untuk mendapatkan bubuk sericin (Gambar 2).

Sericin ditentukan sebesar $0,03 \%, 0,1 \%$, dan $0,3 \%$. Persentase sericin didapat dari masing-masing berat tapioka. Tiga variasi sericin dicampurkan dengan masing-masing bioplastik 1, 2, dan 3 (Tabel 2) menggunakan magnetic stirrer pada putaran $600 \mathrm{rpm}$ dengan suhu $50^{\circ} \mathrm{C}$ selama 7 menit. Biokomposit di cetak dalam bentuk disk dengan cetakan ukuran $15 \times 5 \mathrm{~mm}$ dan dibekukan pada suhu $-25^{\circ} \mathrm{C},-45^{\circ} \mathrm{C}$, dan $-80^{\circ} \mathrm{C}$ selama 1 hari. Selanjutnya dilakukan proses freeze drying selama 1 hari. Teknik purposive sampling digunakan dalam pengambilan sampel dan hanya 9 sampel dari 27 sampel dilakukan uji SEM (Tabel 3).

Tabel 1. Proses pembuatan bioplastik

\begin{tabular}{ccccc}
\hline No & B $(\mathbf{g})$ & $\begin{array}{c}\text { Bioplastik } \\
\text { A (ml) }\end{array}$ & G (ml) & Proses \\
\hline 1 & 16 & & & $16 \mathrm{~g} \mathrm{PT}+80 \mathrm{ml} \mathrm{A}+6 \mathrm{ml} \mathrm{G}$ \\
2 & 14 & 80 & 6 & $14 \mathrm{~g} \mathrm{PT}+80 \mathrm{ml} \mathrm{A}+6 \mathrm{ml} \mathrm{G}$ \\
3 & 10 & & & $10 \mathrm{~g} \mathrm{PT}+80 \mathrm{ml} \mathrm{A}+6 \mathrm{ml} \mathrm{G}$ \\
\hline
\end{tabular}

Persentase pati tapioka didapat dari berat aquades

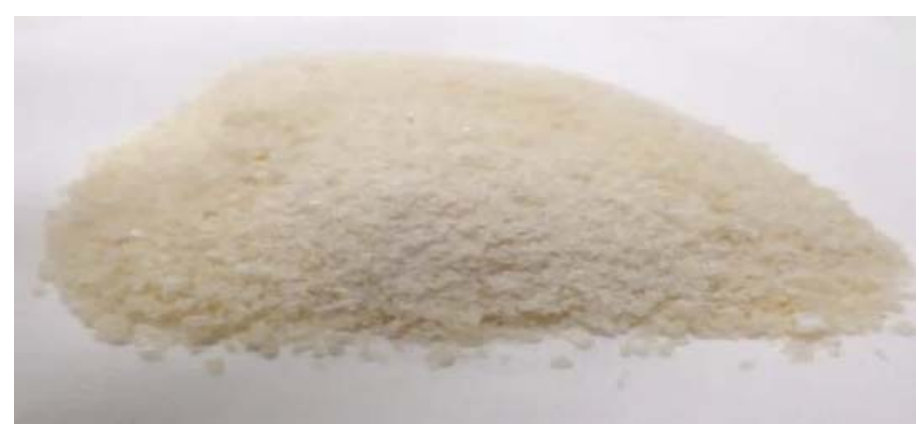

Gambar 2. Bubuk sericin hasil freeze drying selama 2 hari

Tabel 2. Komposisi Biokomposit A s/d I

\begin{tabular}{cccc}
\hline \multirow{2}{*}{ Bioplastik } & \multicolumn{2}{c}{ Sericin } & Proses \\
& $\%$ & G & Biokomposit \\
\hline \multirow{2}{*}{1} & 0,03 & 0,0048 & A: Bioplastik 1 + 0,0048g sericin \\
& 0,1 & 0,016 & B: Bioplastik 1 + $0,016 \mathrm{~g}$ sericin \\
\hline
\end{tabular}




\begin{tabular}{|c|c|c|c|c|c|}
\hline & & & \multicolumn{3}{|c|}{ C: Bioplastik $1+\quad 0,048 \mathrm{~g}$ sericin } \\
\hline \multirow{3}{*}{2} & 0,03 & 0,0042 & D: Biopl & $+0,00$ & ericin \\
\hline & 0,1 & 0,014 & E: Biopla & & ericin \\
\hline & 0,3 & 0,042 & F: Biopla & 0,0 & ericin \\
\hline \multirow{3}{*}{3} & 0,03 & 0,003 & G: Biopl & $+0,0$ & ericin \\
\hline & 0,1 & 0,01 & H: Biopl & & ricin \\
\hline & 0,3 & 0,03 & I: Biopl & $+\quad 0,0$ & ricin \\
\hline \multicolumn{6}{|c|}{$\%$ sericin ditentukan terhadap berat pati tapioka $16 \mathrm{~g}, 14 \mathrm{~g}$, dan $10 \mathrm{~g}$} \\
\hline \multicolumn{6}{|c|}{ Tabel 3. Tabel pengujian SEM sampel biokomposit C, F, dan I } \\
\hline Biokomposit & \multicolumn{2}{|c|}{ Konsentrasi } & \multicolumn{3}{|c|}{ Suhu $\left({ }^{\circ} \mathrm{C}\right)$} \\
\hline $\mathrm{C}$ & \multicolumn{2}{|c|}{ Bioplastik $1+0,048 \mathrm{~g}$ sericin } & & & \\
\hline $\mathrm{F}$ & \multicolumn{2}{|c|}{ Bioplastik $2+0,042 \mathrm{~g}$ sericin } & -25 & -45 & -80 \\
\hline I & \multicolumn{2}{|c|}{ Bioplastik $3+0,03 \mathrm{~g}$ sericin } & & & \\
\hline
\end{tabular}

\subsection{Perencanaan desain eksperimen}

Tahap perencanaan eksperimen sebagai berikut:

1. Identifikasi karakteristik kualitas

Biokomposit yang memenuhi syarat untuk material biokomposit medis khusus nya pada kulit dan tulang.

2. Penentuan faktor berpengaruh dan faktor terkendali
a. Bioplastik
Bioplastik dari campuran pati tapioka, aquades, dan gliserin.
b. Sericin
Sericin diproses melalui metode autoclave dan freeze drying,
c. Suhu pembekuan

3. Penentuan setting level faktor
a. Bioplastik
Aquades $80 \mathrm{ml}$ dan $6 \mathrm{ml}$ gliserin di campur dengan berat pati tapioka $16 \mathrm{~g}, 14 \mathrm{~g}$, dan $14 \mathrm{~g}$.
b. Sericin: $0,03 \%, 0,1 \%$, dan $0,3 \%$
c. Suhu pembekuan: $-25^{\circ} \mathrm{C},-45^{\circ} \mathrm{C}$, dan $-80^{\circ} \mathrm{C}$

\subsection{Perancangan metode Taguchi}

A. Klasifikasi parameter

Beberapa faktor yang mempengaruhi karakteristik kualitas adalah:

1. Faktor noise, parameter penyimpangan karakteristik kualitas dari nilai target.

2. Faktor terkendali, parameter yang nilainya ditentukan oleh peneliti.

3. Faktor signal, faktor yang mengubah nilai karakteristik kualitas.

4. Faktor skala, faktor yang digunakan untuk mengubah rata-rata level karakter.

B. Menentukan Orthogonal Array

$$
\begin{gathered}
d b(\text { level })=l-1 \\
L_{n}=\left(l^{f}\right)
\end{gathered}
$$


C. Analisis varians (ANOVA)

1. Menghitung rata-rata (mean)

$$
\mu_{i}=\frac{1}{n} \sum_{i=1}^{n} y_{i}
$$

2. Signal to Noise Ratio (SNR)

a. Makin kecil makin baik (Smaller the better)

$$
\mathrm{SNR}_{\mathrm{stb}}=-10 \log \left[\frac{1}{\mathrm{n}} \sum_{\mathrm{i}=1}^{\mathrm{n}} \mathrm{y}_{\mathrm{i}}^{2}\right]
$$

b. Makin besar makin baik (larger the better).

$$
S N R_{l t b}=-10 \log \left[\frac{1}{n} \sum_{i=1}^{n} \frac{1}{y_{i}^{2}}\right]
$$

c. Terbaik pada nominal (No minal the better).

$$
S N R_{n t b}=10 \log 10\left[\frac{\mu^{2}}{\sigma^{2}}\right]
$$

\section{HASIL DAN PEMBAHASAN}

\subsection{Hasil pengujian SEM}

Dari gambar SEM pada biokomposit $\mathrm{C}$ pembekuan $-25^{\circ} \mathrm{C}$ dan $-45^{\circ} \mathrm{C}$ jarak pori jauh dan jumlah pori sedikit. Pembekuan $-80^{\circ} \mathrm{C}$ permukaan rapat sehingga ukuran pori kecil (Gambar 4). Biokomposit $\mathrm{F}$ pembekuan $-25^{\circ} \mathrm{C}$ memiliki pori tidak merata. Pembekuan $45^{\circ} \mathrm{C}$ tampak memiliki serat, jarak pori jauh dan permukaan bidang rata. Pembekuan $-80^{\circ} \mathrm{C}$ permukaan bidang sangat rapat dan rata, pori terbentuk hanya di sebagian bidang (Gambar $5)$.

Biokomposit I pembekuan $-25^{\circ} \mathrm{C}$ bidang permukaan rata dan kasar. Pembekuan $45^{\circ} \mathrm{C}$ bidang rata, pori merata pada bidang. Pembekuan $-80^{\circ} \mathrm{C}$ permukaan bidang rapat dan rata, pori terbentuk sedikit (Gambar 6).

Ukuran diameter pori yang terbentuk pada biokomposit C, F, dan I pada pembekuan $-25^{\circ} \mathrm{C},-45^{\circ} \mathrm{C}$, dan $-80^{\circ} \mathrm{C}$ dari uji SEM dibandingakan dengan ukuran rerata pori penelitian yang dilakukan oleh Wang dkk, (2014), dimana Wang dkk, (2014) melakukan penelitian tentang pembekuan hydrogel sericin pada suhu $-20^{\circ} \mathrm{C}(45,22 \mu \mathrm{m}-316,91 \mu \mathrm{m})$, $-80^{\circ} \mathrm{C}(43,4 \mu \mathrm{m}-167,13 \mu \mathrm{m})$, dan $-196^{\circ} \mathrm{C}(6,45 \mu \mathrm{m}-20,56 \mu \mathrm{m})$ (Gambar. 7).

\subsection{Porositas}

Perbandingan ukuran pori yang terbentuk pada biokomposit didapat kisaran pori. Biokomposit $\mathrm{C}$ pembekuan $-25^{\circ} \mathrm{C},-45^{\circ} \mathrm{C}$, dan $-80^{\circ} \mathrm{C}$ kisaran rata-rata adalah $41.94 \pm 16.51$ $\mu \mathrm{m}$ dengan porositas $28.6 \%, 30.147 \pm 5.567 \mu \mathrm{m}$ dengan porositas $31.9 \%$, dan $0.345 \pm 0.129$ $\mu$ m dengan porositas $0.2 \%$. Biokomposit $\mathrm{F}$ pembekuan $25^{\circ} \mathrm{C},-45^{\circ} \mathrm{C}$, dan $-80^{\circ} \mathrm{C}$ kisaran ratarata $33.416 \pm 8.988 \mu \mathrm{m}$ dengan porositas $38.7 \%, 12.317 \pm 4.171 \mu \mathrm{m}$ dengan porositas $15.7 \%$, dan $3.102 \pm 3.461 \mu \mathrm{m}$ dengan porositas 3.2\%. Biokomposit I pembekuan kisaran rata-rata masing-masing adalah $32.743 \pm 11.911 \mu \mathrm{m}$ dengan porositas $38.7 \%, 53.685 \pm 22.972 \mu \mathrm{m}$ dengan porositas $15.7 \%$, dan $3.387 \pm 1.575 \mu \mathrm{m}$ dengan porositas $3.2 \%$. 


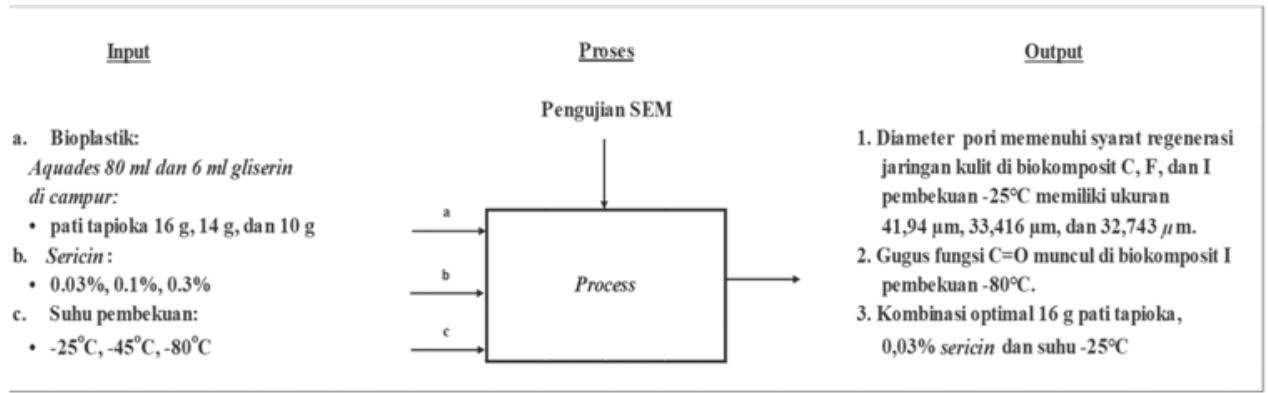

Gambar 3. Sistem input dan output pembuatan biokomposit sericin-bioplastik
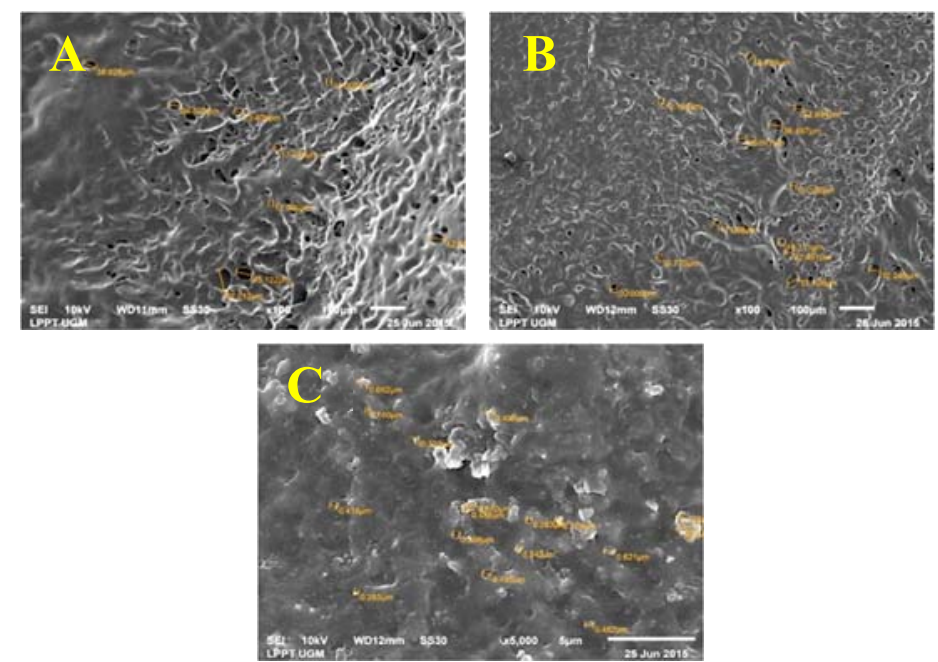

Gambar 4. Hasil SEM biokomposit C pembekuan $\left.\left\{(\mathrm{A})-25^{\circ} \mathrm{C},(\mathrm{B})-45^{\circ} \mathrm{C}, \mathrm{C}\right)-80^{\circ} \mathrm{C}\right\}$
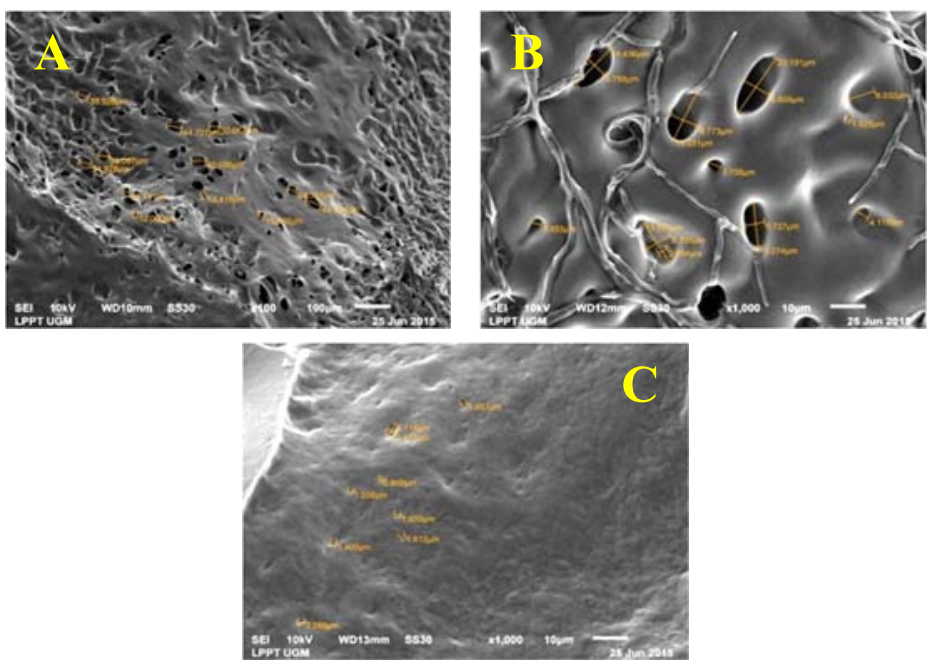

Gambar 5. Hasil SEM biokomposit F pembekuan $\left\{(\mathrm{A})-25^{\circ} \mathrm{C}\right.$, (B) $\left.-45^{\circ} \mathrm{C},(\mathrm{C})-80^{\circ} \mathrm{C}\right\}$ 

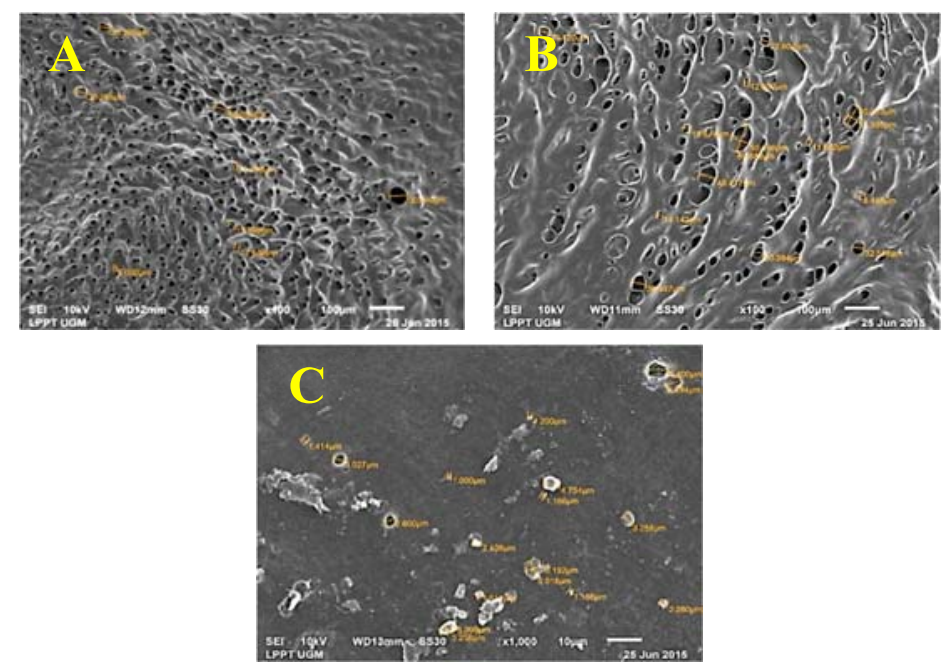

Gambar 6. Hasil SEM biokomposit I pembekuan $\left\{(\mathrm{A})-25^{\circ} \mathrm{C},(\mathrm{B})-45^{\circ} \mathrm{C},(\mathrm{C})-80^{\circ} \mathrm{C}\right\}$
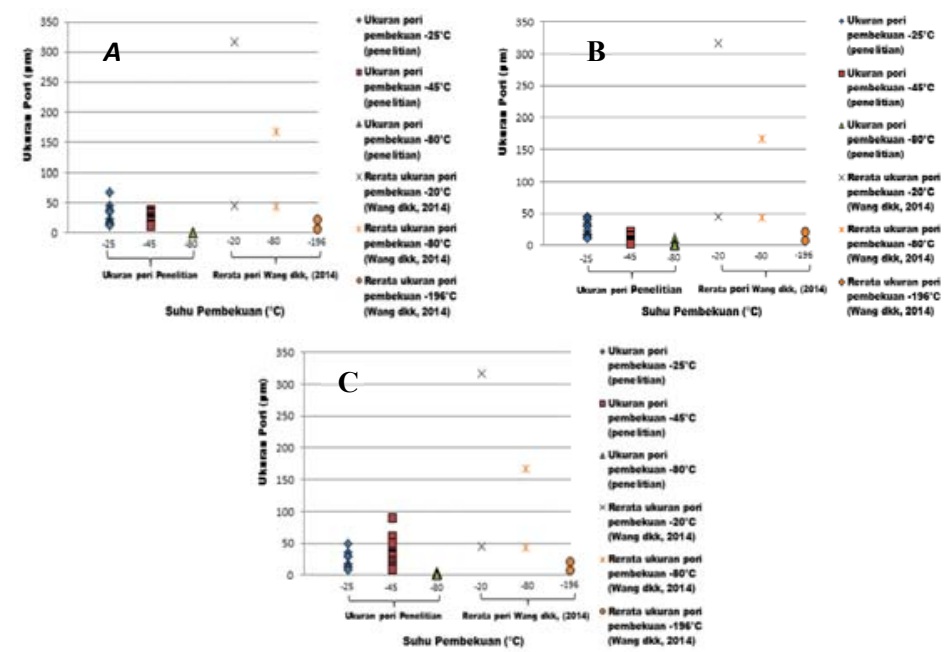

Gambar 7. Perbandingan distribusi pori pembekuan $-25^{\circ} \mathrm{C},-45^{\circ} \mathrm{C}$, dan $-80^{\circ} \mathrm{C}$ dengan pori penelitian Wang dkk, (2014). (A) biokomposit C, (B) biokomposit F, (C) biokomposit I.

\subsection{Eksperimen Taguchi}

Variabel bebas adalah berat pati tapioka (PT) (g), sericin (S) (\%), dan suhu pembekuan $(\mathrm{SP})\left({ }^{\circ} \mathrm{C}\right)$. Sedangkan nilai dari level yaitu pati tapioka $16 \mathrm{~g}, 14 \mathrm{~g}$, dan $10 \mathrm{~g}$. sericin $0,03 \%, 0,1 \%$, dan $0,3 \%$, dan suhu pembekuan $-25^{\circ} \mathrm{C},-45^{\circ} \mathrm{C}$, dan $-80^{\circ} \mathrm{C}$. 


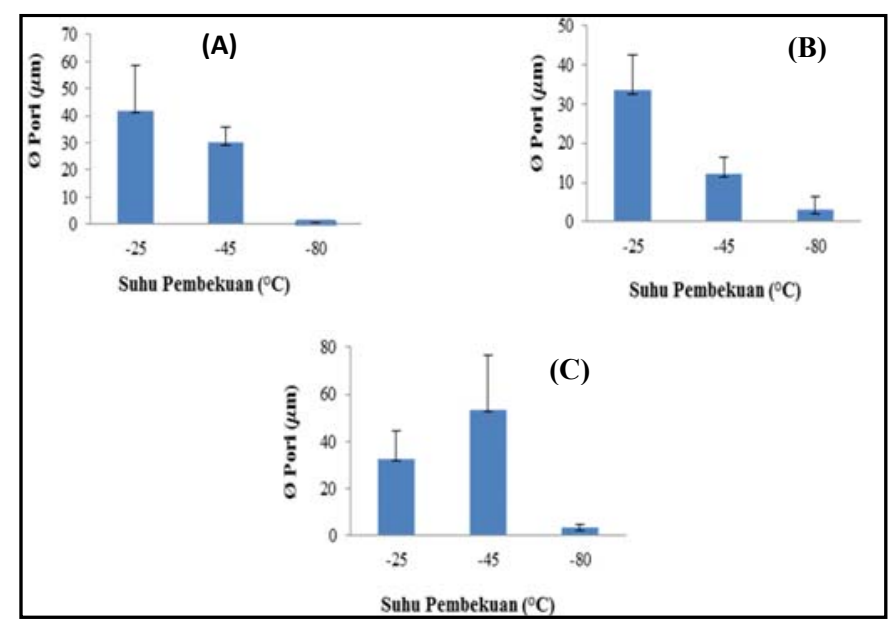

Gambar 8. Rerata diameter pori dan porositas pembekuan $-25^{\circ} \mathrm{C},-45^{\circ} \mathrm{C}$, dan $-80^{\circ} \mathrm{C}$ (A) Biokomposit C, (B) Biokomposit F, (C) biokomposit I

Tabel 4. Variabel bebas dan derajat kebebasan variabel bebas

\begin{tabular}{|c|c|c|c|c|c|}
\hline Variabel Bebas & Level (I) & \multicolumn{3}{|c|}{ Nilai Variabel } & $(l-1)$ \\
\hline PT $(\mathrm{g})$ & 3 & 16 & 14 & 10 & 2 \\
\hline S $(\%)$ & 3 & 0,3 & 0,1 & 0,03 & 2 \\
\hline $\mathrm{SP}\left({ }^{\circ} \mathrm{C}\right)$ & 3 & -25 & -45 & -80 & 2 \\
\hline
\end{tabular}

Berdasarkan perhitungan matrik orthogonal array $(\mathrm{OA})$ adalah $\mathrm{L}_{9}\left(3^{4}\right)$. Jumlah eksperimen 9 kali dengan replikasi 3 kali pada masing-masing sampel. Replikasi dilakukan untuk mengurangi kesalahan dan meningkatkan ketelitian data percobaan. Sehingga jumlah total sampel yang dibuat sebanyak 27 sampel.

Tabel 5. Nilai mean dan nilai Signal to Noise Ratio (SNR)

\begin{tabular}{cccccc}
\hline No. Eksp & A & B & C & $(\boldsymbol{\mu})$ & SNR \\
\hline 1 & 1 & 1 & 1 & 36,374 & 33,275 \\
2 & 1 & 2 & 2 & 27,019 & 30,586 \\
3 & 1 & 3 & 3 & 23,898 & 29,509 \\
4 & 2 & 1 & 2 & 20,587 & 28,123 \\
5 & 2 & 2 & 3 & 17,604 & 26,866 \\
6 & 2 & 3 & 1 & 15,074 & 25,583 \\
7 & 3 & 1 & 3 & 13,444 & 24,750 \\
8 & 3 & 2 & 1 & 11,439 & 23,173 \\
9 & 3 & 3 & 2 & 9,484 & 21,565 \\
\hline
\end{tabular}


Data penelitian adalah ukuran diameter pori biokomposit pada gambar SEM. Hasil perhitungan mean dan SNR pada Tabel 5.

B. Nilai mean respon.

$$
\mu_{1}=36,374
$$

C. Nilai Signal to Noise Ratio (SNR).

$\eta_{1}=33,275$

\subsection{Anova respon nilai rata-rata (mean)}

Perhitungan Anova untuk mencari faktor mempengaruhi nilai respon mean.

A. Nilai mean semua data percobaan

$\bar{Y}=19,436$

B. Nilai mean setiap faktor dan level

Tabel 6. Respon nilai mean dari pengaruh faktor dan level

\begin{tabular}{cccccc}
\hline \multirow{2}{*}{ Variabel } & Kode & $\mathbf{1}$ & $\mathbf{2}$ & $\mathbf{3}$ & Selisih \\
\hline PT & A & $\mathbf{2 9 , 0 9}$ & 17,76 & 11,46 & 17,64 \\
S & B & $\mathbf{2 3 , 4 7}$ & 18,69 & 16,15 & 7,32 \\
SP & C & $\mathbf{2 0 , 9 6}$ & 19,03 & 18,32 & 2,65 \\
\hline
\end{tabular}

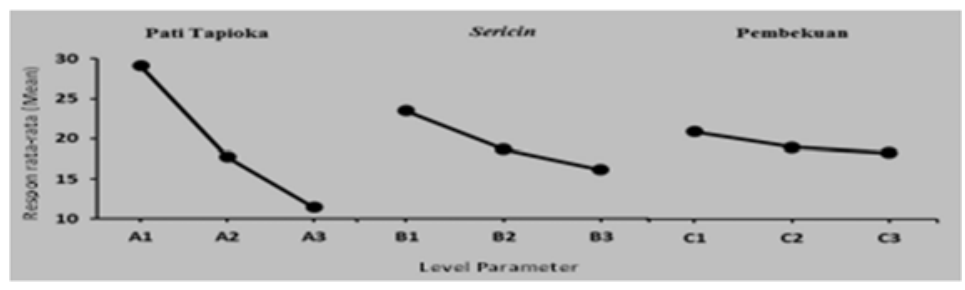

Gambar 9 Grafik respon nilai mean dari pengaruh faktor dan level

Berdasarkan Tabel 6, respon mean faktor pati tapioka pada level $A_{1}$, sericin pada level $\mathrm{B}_{1}$, dan suhu pembekuan pada level $\mathrm{C}_{1}$.

C. Nilai sum of square.

$\mathrm{ST}=56783,57$

D. Nilai sum of squares due to mean.

$\mathrm{SS}_{\mathrm{m}}=3399,80$

E. Nilai sum of squares due to factors.

$\mathrm{SS}_{\mathrm{A}}=8238,19, \quad \mathrm{SS}_{\mathrm{B}}=7048,06$

$\mathrm{SS}_{\mathrm{C}}=6833,36$

F. Nilai sum of squares due to error:

SSe $=31264,15$

G. Nilai derajat bebas.

$\mathrm{db}\left(\right.$ level) $\mathrm{v}_{\mathrm{A}, \mathrm{B}, \mathrm{C}}=3-1=2$

$\mathrm{H}$. Nilai mean sum of squares.

$\mathrm{Mq}_{\mathrm{A}}=4119,09, \mathrm{Mq}_{\mathrm{B}}=3524,03$

$\mathrm{Mq}_{\mathrm{C}}=3416,68, \quad \mathrm{MS}_{\mathrm{e}}=422,48$ 
I. Nilai F-ratio.

$\mathrm{Fr}_{\mathrm{A}}=9,75, \mathrm{Fr}_{\mathrm{B}}=8,34, \mathrm{Fr}_{\mathrm{C}}=8,087$

J. Nilai pure sum of squares.

$\mathrm{SS}^{\prime}{ }_{\mathrm{A}}=7393,22, \mathrm{SB}_{\mathrm{B}}{ }_{\mathrm{B}}=6203,087$

$\mathrm{SC}^{\prime}{ }_{\mathrm{C}}=5988,381, \mathrm{st}=53383,770$

$\mathrm{S}_{\mathrm{e}}^{\prime}=33799,084$

K. Nilai percent contribution.

$\rho_{\mathrm{A}}=13,849 \%, \rho_{\mathrm{B}}=11,620 \%, \rho_{\mathrm{C}}=11,218 \%$

Pooling up dilakukan terhadap faktor $\mathrm{Mq}_{\mathrm{error}}$ dan nilai sum of squares yang terkecil (Tabel 9).

\subsection{Anova respon nilai signal to noise ratio (SNR)}

A. Nilai SNR setiap faktor dan level.

\begin{tabular}{cccccc}
\multicolumn{6}{c}{ Tabel 7. Respon nilai SNR dari pengaruh faktor dan level } \\
\hline Variabel & Kode & $\mathbf{1}$ & $\mathbf{2}$ & $\mathbf{3}$ & Selisih \\
& & & & \\
\hline PT & A & $\mathbf{3 1 , 1 2}$ & 26,86 & 23,16 & 7,96 \\
S & B & $\mathbf{2 8 , 7 2}$ & 26,88 & 25,55 & 3,16 \\
SP & C & $\mathbf{2 7 , 3 4}$ & 26,76 & 27,04 & 0,59 \\
\hline
\end{tabular}

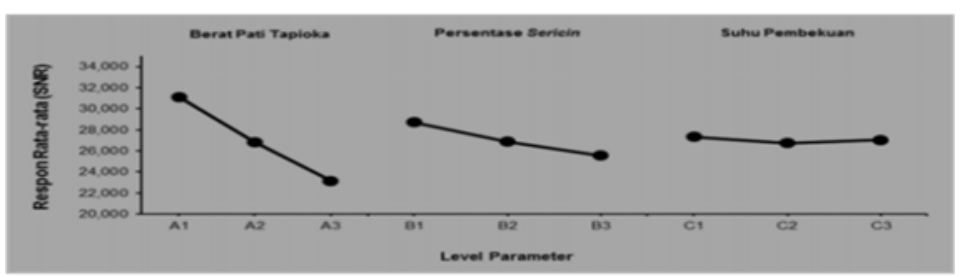

Gambar 10. Grafik respon nilai SNR dari pengaruh faktor dan level

Berdasarkan Tabel 7, pemilihan respon SNR pati tapioka pada level $A_{1}$, sericin pada level $\mathrm{B}_{1}$, dan suhu pembekuan pada level $\mathrm{C}_{1}$

B. Nilai total sum of squares.

$\mathrm{ST}=6695,277$

C. Nilai sum of squares due to the mean.

$\mathrm{SS}_{\mathrm{m}}=6584,245$

D. Nilai sum of square due to factors.

$\mathrm{SS}_{\mathrm{A}}=95,212, \quad \mathrm{SS}_{\mathrm{B}}=15,147$

$\mathrm{SS}_{\mathrm{C}}=0,514$

E. Nilai sum of squares due to error:

$\mathrm{SSe}=0,160$

F. Nilai derajat bebas sumber-sumber variansi.

$\mathrm{db}$ (level) $\mathrm{v}_{\mathrm{A}, \mathrm{B}, \mathrm{C}}=3-1=2$

G. Nilai mean sum of squares.

$\mathrm{Mq}_{\mathrm{A}}=47,606, \mathrm{Mq}_{\mathrm{B}}=7,573$,

$\mathrm{Mq}_{\mathrm{C}}=0,257, \mathrm{MS}_{\mathrm{e}}=0,002$

H. Nilai F-ratio. Persamaan (4.37)

$\mathrm{Fr}_{\mathrm{A}}=21965,95, \mathrm{Fr}_{\mathrm{B}}=3494,43$ 
$\mathrm{Fr}_{\mathrm{C}}=118,597$

I. Nilai pure sum of squares.

$\mathrm{SS}_{\mathrm{A}}^{\prime}=95,207, \mathrm{SB}_{\mathrm{B}}^{\prime}=15,142$

$\mathrm{SC}_{\mathrm{C}}^{\prime}=0,510$, st $=111,033$

$\mathrm{S}_{\mathrm{e}}^{\prime}=0,173$

J. Nilai percent contribution.

$\rho_{\mathrm{A}}=85,747 \%, \rho_{\mathrm{B}}=13,638 \%$

$\rho_{\mathrm{C}}=0,459 \%$

Pooling dilakukan dengan melakukan pool faktor $\mathrm{C}$ ke dalam error karena nilai $\mathrm{Mq}$ nya kecil (Tabel 11).

\subsection{Prediksi respon dan selang kepercayaan kondisi optimal nilai mean}

Nilai mean seluruh data percobaan adalah $\bar{y}=19,436$, maka perhitungan respon mean prediksi adalah:

$$
\begin{aligned}
\mu_{\text {predicted }} & =\overline{A 1}+\overline{B 1}-\bar{y} \\
& =29,097+23,468-19,436 \\
& =33,1 \mu \mathrm{m}
\end{aligned}
$$

Selang kepercayaan mean prediksi:

$C I_{\text {Mean }}= \pm \sqrt{4,967 \times 501,283 \times\left[\frac{1}{5,4}\right]}$

$C I_{\text {Mean }}= \pm 21,5 \mu \mathrm{m}$

Sehingga selang kepercayaan nilai mean proses yang optimal adalah:

$33,1-21,5 \leq \mu_{\text {predicted }} \leq 33,1+21,5$

$11,656 \mu m \leq \mu_{\text {predicted }} \leq 54,602 \mu m$

Tabel 8. Analysis of variance mean

\begin{tabular}{|c|c|c|c|c|c|c|c|}
\hline Faktor & Pool & SS & $\mathbf{v}$ & Mq & Fr & SS' & $\rho \%$ \\
\hline A & & 8238,196 & 2 & 4119,098 & 8,217 & 7235,629 & 13,554 \\
\hline B & & 7048,064 & 2 & 3524,032 & 7,030 & 6045,498 & 11,325 \\
\hline Pooled e & & 38097,511 & 76 & 501,283 & 1 & 40102,643 & 75,121 \\
\hline st & & 53383,770 & 80 & 667,297 & & 53383,770 & 100 \\
\hline Mean & & 3399,801 & 1 & & & & \\
\hline
\end{tabular}

\begin{tabular}{ccccccc}
\hline Faktor & SS & $\mathbf{v}$ & $\mathbf{M q}$ & $\mathbf{F r}$ & $\mathbf{S S}^{\prime}$ & $\boldsymbol{\rho} \%$ \\
\hline A & 8238,196 & 2 & 4119,098 & 9,750 & 7393,218 & 13,849 \\
B & 7048,064 & 2 & 3524,032 & 8,341 & 6203,087 & 11,620 \\
C & 6833,359 & 2 & 3416,679 & 8,087 & 5988,381 & 11,218 \\
e & 31264,153 & 74 & 422,489 & 1 & 33799,084 & 63,313 \\
st & 53383,770 & 80 & 667,297 & - & 53383,770 & 100 \\
Mean & 3399,801 & 1 & - & - & - & - \\
\hline
\end{tabular}

Tabel 9. Hasil setelah Pooling up mean 
Jurnal Optimalisasi

Vol 3 Nomor 5 OKTOBER 2017

P. ISSN : 2477-5479

E. ISSN : 2502-0501

Tabel 10. Analysis of variance SNR

\begin{tabular}{ccccccc}
\hline Faktor & SS & $\mathbf{v}$ & $\mathbf{M q}$ & $\mathbf{F r}$ & $\mathbf{S S}^{\prime}$ & $\boldsymbol{\rho} \%$ \\
\hline A & 95,212 & 2 & 47,606 & 21965,952 & 95,207 & 85,747 \\
B & 15,147 & 2 & 7,573 & 3494,433 & 15,142 & 13,638 \\
C & 0,514 & 2 & 0,257 & 118,597 & 0,510 & 0,459 \\
e & 0,160 & 2 & 0,002 & 1 & 0,173 & 0,156 \\
st & 111,033 & 8 & 13,879 & - & 111,033 & 100 \\
Mean & 6584,245 & 1 & - & - & - & - \\
\hline
\end{tabular}

Tabel 11. Hasil setelah Pooling up SNR

\begin{tabular}{|c|c|c|c|c|c|c|c|}
\hline Faktor & Pool & SS & $\mathbf{v}$ & Mq & $\mathrm{Fr}$ & SS & $\boldsymbol{\rho} \%$ \\
\hline $\mathrm{A}$ & & 95,212 & 2 & 47,606 & 282,343 & 94,874 & 85,447 \\
\hline B & & 15,147 & 2 & 7,573 & 44,916 & 14,809 & 13,338 \\
\hline Pooled e & & 0,674 & 4 & 0,169 & 1 & 1,349 & 1,215 \\
\hline st & & 111,033 & 8 & 13,879 & - & 111,033 & 100 \\
\hline Mean & & 6584,245 & 1 & - & - & - & - \\
\hline
\end{tabular}

\subsection{Prediksi respon dan selang kepercayaan kondisi optimal nilai SNR.}

Nilai rata-rata SNR seluruh data percobaan adalah $\bar{\eta}=27,048$, maka perhitungan respon SNR prediksi adalah:

$$
\begin{aligned}
\mu_{\text {predicted }} & =\overline{A 1}+\overline{B 1}-\bar{\eta} \\
& =31,123+28,716-27,048 \\
& =32,8 \mu \mathrm{m}
\end{aligned}
$$

Selang kepercayaan SNR prediksi:

$C I_{S N R}= \pm \sqrt{7,709 \times 0,169 \times\left[\frac{1}{1,8}\right]}$

$C I_{S N R}= \pm 0,9 \mu \mathrm{m}$

Sehingga selang kepercayaan untuk SNR proses yang optimal adalah:

$32,8-0,9 \leq S N R_{\text {predicted }} \leq 32,8+0,85$

$31,940 \mu \mathrm{m} \leq S N R_{\text {predicted }} \leq 33,642 \mu \mathrm{m}$

\subsection{Selang keperayaan nilai eksperimen konfirmasi}

Perhitungan selang kepercayaan nilai eksperimen konfirmasi untuk nilai mean dan SNR di bagi ke dalam dua kelompok yaitu ukuran diameter pori besar dan kecil.

1. Untuk nilai mean

$$
\begin{aligned}
& C I_{\text {Mean }}= \pm \sqrt{4,97 \times 501,28 \times\left[\frac{1}{5,4}+\frac{1}{9}\right]} \\
& C I_{\text {Mean }}= \pm 27,16 \mu \mathrm{m}
\end{aligned}
$$

2. Untuk nilai SNR 


$$
\begin{aligned}
& C I_{S N R}= \pm \sqrt{7,71 \times 0,17 \times\left[\frac{1}{1,8}+\frac{1}{9}\right]} \\
& C I_{S N R}= \pm 0,93 \mu \mathrm{m}
\end{aligned}
$$

A. Diameter pori besar

Tabel 12. Data hasil penelitian pori besar

\begin{tabular}{cccccccc}
\hline No. & $\begin{array}{c}\text { Diameter } \\
\text { pori }(\boldsymbol{\mu m})\end{array}$ & No. & $\begin{array}{c}\text { Diameter } \\
\text { pori }(\boldsymbol{\mu m})\end{array}$ & $\begin{array}{c}\text { Rata- } \\
\text { rata }\end{array}$ & Variansi & Deviasi & SNR \\
\hline 1 & 67,912 & 6 & 12,000 & 36,37 & 902,67 & 30,045 & 33,27 \\
2 & 36,497 & 7 & 50,040 & & & & \\
3 & 0,495 & 8 & 89,889 & & & & \\
4 & 44,944 & 9 & 5,400 & & & & \\
5 & 20,191 & - & - & & & & \\
\hline
\end{tabular}

Dari Tabel 12, rata-rata 36,37 $\mu m$, nilai SNR 33,27 $\mu$ m, maka selang kepercayaan proses konfirmasi:

1. untuk mean:

$$
\begin{aligned}
36,37-27,16 & \leq \mu_{\text {conf }} \leq 36,37+27,16 \\
9,213 \mu m & \leq \mu_{\text {conf }} \leq 63,535 \mu m
\end{aligned}
$$

2. untuk SNR

$$
\begin{gathered}
33,27-0,93 \leq \mu_{\text {conf }} \leq 33,27+0,93 \\
32,342 \mu m \leq \mu_{\text {conf }} \leq 34,206 \mu m
\end{gathered}
$$

B. Diameter pori kecil

Tabel 13. Data hasil penelitian pori kecil

\begin{tabular}{cccccccc}
\hline No. & $\begin{array}{c}\text { Diameter } \\
\text { pori }(\boldsymbol{\mu m})\end{array}$ & No. & $\begin{array}{c}\text { Diameter } \\
\text { pori }(\boldsymbol{\mu m})\end{array}$ & $\begin{array}{c}\text { Rata- } \\
\text { rata }\end{array}$ & Variansi & Deviasi & SNR \\
\hline 1 & 12,000 & 6 & 0,800 & 6,13 & 25,875 & 5,087 & 17,82 \\
2 & 10,770 & 7 & 8,000 & & & & \\
3 & 0,160 & 8 & 8,485 & & & & \\
4 & 12,000 & 9 & 1,414 & & & & \\
5 & 1,523 & - & - & & & & \\
\hline
\end{tabular}

Dari Tabel 13, rata-rata $6,13 \mu \mathrm{m}$, nilai SNR $17,82 \mu \mathrm{m}$, maka selang kepercayaan proses konfirmasi:

1. untuk mean:

$$
\begin{gathered}
6,13-27,161 \leq \mu_{\text {conf }} \leq 6,128+27,161 \\
-21,033 \mu m \leq \mu_{\text {conf }} \leq 33,289 \mu m
\end{gathered}
$$

2. untuk SNR

$$
\begin{gathered}
17,82-0,93 \leq \mu_{\text {conf }} \leq 17,82+0,93 \\
16,889 \mu m \leq \mu_{\text {conf }} \leq 18,753 \mu m
\end{gathered}
$$




\section{KESIMPULAN}

Diameter pori memenuhi syarat untuk untuk regenerasi jaringan kulit menurut Wang dkk, (2014) adalah $20 \sim 125 \mu \mathrm{m}$, nilai ini cocok dengan diameter pori pembekuan $25^{\circ} \mathrm{C}$ biokomposit C: $41,94 \mu \mathrm{m}, \mathrm{F}: 33,416 \mu \mathrm{m}$ dan I: $32,743 \mu \mathrm{m}$. Pembekuan $-45^{\circ} \mathrm{C}$ biokomposit C: 30,147 $\mu \mathrm{m}$ dan F: 53,685 $\mu \mathrm{m}$. Perhitungan respon mean dan SNR didapat urutan rancangan maksimal yaitu berat pati tapioka $16 \mathrm{~g}$ (A1), persentase sericin $0,03 \%$ (B1), dan suhu pembekuan $-25^{\circ} \mathrm{C}(\mathrm{C} 1)$. Perhitungan nilai prediksi respon dan selang kepercayaan didapat mean prediksi besar dari 11,656 $\mu \mathrm{m}$ dan kecil dari 54,602 $\mu \mathrm{m}$. SNR prediksi besar dari 31,940 $\mu \mathrm{m}$ dan kecil dari 33,642 $\mu \mathrm{m}$. Kondisi optimal eksperimen konfirmasi nilai mean diameter pori besar, besar dari 9,213 $\mu \mathrm{m}$ dan kecil dari 63,535 $\mu \mathrm{m}$. Untuk SNR besar dari 32,342 $\mu \mathrm{m}$ dan kecil dari 34,206 $\mu \mathrm{m}$, Kondisi optimal eksperimen konfirmasi nilai mean diameter pori kecil, besar dari -21,033 $\mu \mathrm{m}$ dan kecil dari 33,289 $\mu \mathrm{m}$. SNR besar dari $16,889 \mu \mathrm{m}$ dan kecil dari $18,753 \mu \mathrm{m}$.

\section{SARAN}

1. Kontrol waktu untuk pembekuan perlu difariasikan, karena bisa mempengaruhi ukuran makroporous dan kekuatan biokomposit tersebut.

2. Untuk melakukan pembekuan $-25^{\circ} \mathrm{C},-45^{\circ} \mathrm{C}$, dan $-80^{\circ} \mathrm{C}$, mesin pendingin sebaiknya dilakukan disatu tempat, agar tidak ada perbedaan perlakuan saat proses freeze drying.

\section{DAFTAR PUSTAKA}

[1] Herliansyah, M.K., Muzafar, C., Tontowi, A.E., 2012, Natural Bioceramics Bone Graft: A Comparative Study of Calcite Hydroxyapatite, Gypsum Hydroxyapatite, Bovine Hydroxyapatite and Cuttlefish Shell Hydroxyapatite, Proceedings of the Asia Pacific Industrial Engineering \& Management Systems Conference.

[2] Ichsan, M.Z., Siswanto., Hikmawati, D., 2013, Sintesis Komposit KolagenHidroksiapatit Sebagai Kandidat Bone Graft, Jurnal Fisika dan Terapannya, Vol 1, No.1, Januari 2013. Hal 2-3.

[3] Kundu, S.C., Dash, B.C., Dash, R., Kaplan, D.L., 2008, Natural Protective Glue Protein, Sericin Bioengineered by Silkworms: Potential for Biomedical and Biotechnological Applications, Progress in Polymer Science., 33: 998-1012.

[4] Hoenich, N., 2006, Cellulose for Medical Applications: Past, Present, and Future. BioRes. 1 (2).270-280.

[5] Ciechańska, D., 2004, Multifunctional Bacterial Cellulose/Chitosan Composite Material for Medical Applications. Journal of Fibres \& Textiles in Eastern Europe. Vol. 12. No. 4.48. 